\title{
PENGUSIRAN MASSAL PENGUNGSI AFRIKA UTARA DARI JERMAN DAN PERMASALAHANNYA
}

\author{
Gibson Radityo \\ (Mahasiswa Program S1 Fakultas Hukum Universitas Tarumanagara) \\ (E-mail: samuelgibson17@yahoo.com)
}

\section{Ida Kurnia}

(Corresponding Author)

(Dosen Hukum Internasional Fakultas Hukum Universitas Tarumanagara, Meraih Sarjana Hukum dari

Fakultas Hukum Universitas Diponogoro, Magister Hukum dari Fakultas Hukum Universitas

Tarumanagara, Doktor Hukum dari Fakultas Hukum Universitas Gadjah Mada)

(E-mail: idah@ @h.untar.ac.id)

\begin{abstract}
United Nation High Commissioner of Refugee (UNHCR) is an internasional organization made under United Nations (UN) specifically for asylum seeker and refugee issues. As an international organization, UNHCR have a legal personality which is give them power to do such a legal action, yet from that power make UNHCR also gets its rights and respondsibility. According to UNHCR statute, Vienna Convention 1951 and Protocol 1967, one of UNHCR respondsibility is to protect and keep the refugee safe and make sure the third parties nation do all the responsibility to keep and protect the refugee. But how, if there is an issue that a nation break the international convention for refugee by force the refugee back to their home, yet the refugees already proved to do crimes againts the third parties nation policy? yet if the refugees forced back to their origin couuntry, they will be threathened, so how suppose the UNHCR as an international organization for refugee do according to the UNHCR statute and Convention of refugees?in that case it will give a responsibility for UNHCR to solve the issue for the refugee. As the case above, the author have an insterest to summarizes the issue as my thesis.
\end{abstract}

Keywords : UNHCR, Refugee, Legal Personality, Respondsibility. 


\section{PENDAHULUAN}

\section{A. Latar Belakang}

Dalam melindungi sebuah negara, seorang pemimpin atau kepala negara harus membuat suatu keputusan tegas dalam menjaga keharmonisan serta keamanan nasional suatu negara. Namun, melihat dari kepentingan untuk melindungi hak-hak kenegaraan tersebut, negara tentu tidak dapat mengesampingkan hak-hak setiap manusia yang memang juga harus dilindungi walaupun bukanlah warga negara di wilayah negara tersebut.

Sebelumnya, di dalam hukum internasional dalam suatu migrasi yang dilakukan seseorang diistilahkan sebagai orang asing (alien), walau tidak semua orang asing dapat dianggap sebagai alien terbagi atas empat (4) kategori umum. Pertama, alysium seeker (pencari suaka). ${ }^{1)}$ Kedua, displaced person (orang terlantar). Ketiga, stateless (orang tanpa kewarganegaraan). Keempat, refugee (pengungsi). ${ }^{2)}$

Dalam hal ini Penulis melihat pada pertanggungjawaban United Nations of High Commissioner For Refugees (selanjutnya disingkat menjadi UNHCR) atas kebijakan pemerintahan negara-negara yang telah melakukan pengusiran terhadap pengungsi, terutama Penulis membahas melalui studi kasus mengenai negara Jerman yang melakukan pengusiran secara massal terhadap pengungsi dari Afrika Utara yang seharusnya pengungsi mendapat jaminan haknya untuk menerima perlindungan oleh hukum internasional. ${ }^{3)}$

1) Perbedaan yang paling utama dari pencari suaka dengan pengungsi adalah bahwa pencari suaka merupakan seseorang yang telah mengajukan permohonan untuk mendapatkan perlindungan namun permohonannya masih dalam proses penentuan oleh UNHCR. Dalam hal ini, individu yang telah mengajukan sudah dalam perlindungan UNHCR tapi belum memperoleh status pengungsi. UNHCR hanya memberikan sertifikat pencari suaka sementara. Sedangkan pengungsi telah memperoleh sertifikat pengungsi dan setiap negara anggota harus menerima pengungsi ini sebagai subjek hukum internasional yang harus dilindungi.

2) Wagiman, Hukum Pengungsi Internasional, Cetakan ke-1, (Jakarta: Sinar Grafika, 2012), hal.54.

3 ) Kate Jastram and Marilyn Achiron, Refugee Protection: A Guide to International Refugee Law, (Switzerland: Inter-Parliamentary Union, 2001), Pg.14. 
Sebagai suatu organisasi internasional yang memiliki fungsi khusus penanganan pengungsi UNHCR terikat pada United Nations High Commissioner For Refugees Statute (selanjutnya disingkat menjadi Statuta UNHCR). Salah satu fungsi umum UNHCR sebagai bagian dari United Nations (PBB) sebagaimana tercantum dalam Statuta UNHCR BAB II Pasal 6 adalah membantu proses pengurusan dan pemberian perlindungan terhadap setiap individu-individu yang membutuhkan pertolongan dan perlindungan negara lain.

Dalam Hukum internasional terutama di dalam permasalahan pengungsi diatur dalam Konvensi Wina 1951 tentang Pengungsi, yang diperkuat oleh Protokol 1967. Dalam Pasal 33 Konvensi Wina 1951, secara jelas menyatakan setiap pengungsi tidak boleh dipulangkan dalam keadaan apapun. Selanjutnya, ada pula beberapa prinsip-prinsip internasional ${ }^{4)}$ yang juga berkembang dalam masyarakat internasional yang mejadi tolok ukur dalam larangan melakukan tindakan-tindakan yang berhubungan dengan pengusiran-pengusiran oleh negara suaka terhadap pengungsi yang telah memiliki status pengungsi.

Namun disisi lain selain prinsip-prinsip yang mengikat negara tentunya, sebagai pengungsi juga memiliki suatu tanggung jawab dan kewajiban yang harus ditaatinya selagi menerima hak-haknya sebagai pengungsi. Kewajiban pengungsi ini adalah harus menghormati segala kedaulatan dan peraturan-peraturan yang berlaku di negara di mana ia tinggal serta ketentuan-ketentuan umum internasional yang menjadi kewajiban pengungsi.

Pengungsi Afrika Utara telah mulai bermigrasi untuk mencari suaka dimulai sejak akhir tahun 2015 yang didorong karena perang yang terjadi di Suriah, sehingga telah mendorong setidaknya 4.9 juta orang untuk pergi mencari suaka. Konflik di irak yang juga menghasilkan $1 / 4$ juta populasi yang menjadi

\footnotetext{
4) selain dari pada prinsip non-refoulment ada pula prinsip-prinsip seperti: security of refugee, Prohibition againts detention of refuge, gainful employment of refuge, dan ptinsip-prinsip lainnya yang terkandung dalam Konvensi WINA 1951 yang mengikat negara-negara peserta dan negara-negara bukan peserta.
} 
pengungsi sehingga menghasilkan perpindahan pengungsi terbesar ke eropa di banding kawasan lainnya. ${ }^{5)}$

Pengungsi Afrika Utara, tepatnya daerah Maroko disamping adanya konflik di Suriah, juga merupakan daerah yang secara geografis memang berdekatan dengan daerah konflik Timur Tengah juga terdapat krisis teror yang dilakukan ISIS terhadap negara-negara secara global. Hal inilah yang menjadi dasar pertimbangan UNHCR sebagai lembaga tinggi PBB untuk menerima warga Afrika Utara yang mencoba untuk mencari perlindungan ke Eropa dan yang menjadi Negara tujuan adalah Jerman. Dalam hal ini, wilayah yang dianggap aman oleh pengungsi adalah Eropa. Fakta menujukkan bahwa negara-negara eropa lebih mudah dalam menerima pengungsi karena terdapat pernyataan bahwa mereka terbuka atas dasar rasa perang yang dulu pernah ada sejak Perang Dunia II, sehingga atas dasar kemanusiaan lebih membuka diri dalam pelayanan terhadap para pencari suaka, kemudian juga dengan perkembangan ekonomi di eropa yang dianggap baik dan mampu membantu pengungsi-pengungsi dalam mencari perlindungan. ${ }^{6)}$

Didalam perkembangannya, pengungsi dari Afrika Utara, yang telah sampai ke Negara tujuan dalam hal ini Negara Jerman, melakukan suatu tindakan yang menurut aturan hukum nasional Jerman tidak dapat ditoleransi. Konflik permasalah antara pengungsi Afrika Utara dimulai sejak terjadinya kasus pelecehan seksual massal pada malam tahun baru di kota Köln, pemerintah Jerman dimana diperkirakan sekitar 1.000 orang pengungsi yang diduga adalah dari Afrika Utara melakukan pesta tahun baru kemudian setelah dibubarkan mereka membentuk koloni-koloni kecil dan melakukan penyerangan seksual terhadap wanita warga negara Jerman. Perlu dilihat fakta menarik dalam hal ini atas kasus pelecehan tersebut Jerman memutuskan pemulangan pengungsi secara

5) Anonim, "Dengan 1 dari 113 orang yang terkena dampaknya, perpindahan terpaksa mencapai rekor tertinggi", http://www.unhcr.org/id/wp-content/uploads/sites/42/2017/05/wrdreleasebhs16.pdf, 6 Maret 2018, hal.4.

${ }^{6)}$ Anonim, Loc.Cit, hal.4. 
paksa dan berupaya mempercepat proses deportasi pengungsi Afrika Utara dalam jumlah belasan ribu. ${ }^{7)}$

Walaupun pemerintah di Maroko dan Aljazair sepakat menerima kembali warga negaranya yang mengungsi dengan alasan ekonomi ke Jerman. Kesediaan kedua negara ini membuka jalan proses deportasi cepat. Namun, tentunya perlu diperhatikan apakah negara asal tersebut dapat dikatakan layak untuk menerima kembali pengungsi tersebut, apakah keselamatan dan nyawa pengungsi akan aman apabila dikembalikan ke negara asalnya. Walaupun Jerman menggolongkan Maroko, Aljazair, dan Tunisia sebagai negara aman, ${ }^{8)}$ tentunya apabila benar adanya aman tidak lah mungkin UNHCR akan memberikan sertifikat status pengungsi terhadap pengungsi Afrika Utara tersebut.

Melihat pengusiran tersebut Penulis menemukan suatu permasalahan yang menarik tentunya sebagai suatu lembaga tinggi dari Perserikatan Bangsa-Bangsa (PBB), tentunya UNHCR harus bertindak secara tegas atas pengusiran massal ini karena apabila dikembalikan ke negara asal, maka dapat dikatakan nyawa pengungsi-pengungsi ini akan sangat terancam keberadaannya. Sedangkan sebagai pengungsi dari Afrika Utara mereka juga tentunya memiliki sertifikat khusus yang diberikan UNHCR untuk menjamin keberadaan mereka di negara suaka yang menjadi tujuan mereka. Berdasarkan latar belakang tersebut, maka Penulis tertarik untuk melakukan kajian lebih lanjut mengenai topik tersebut dan menuangkannya dalam bentuk tulisan jurnal.

\section{B. Permasalahan}

Berdasarkan uraian latar belakang di atas, maka rumusan permasalahan sebagai berikut:

1. Dapatkah negara diminta untuk pertanggung jawaban atas pengusiran pengungsi yang telah melakukan tindak pidana?

7) Ervan Hardoko, “Jerman Segera Deportasi Masssal Pengungsi Afrika Utara”, http://internasional.kompas.com/read/2016/03/01/19373611/www.dw.com, 9 Februari 2018, hal.1.

${ }^{8)}$ Anonim, Loc.Cit, hal.1. 
2. Bagaimana pertanggung jawaban UNHCR terhadap pengungsi Afrika Utara yang telah diusir dari Jeman atas tindak pidana pelecehan seksual?

\section{Metode Penelitian}

Teknik pengumpulan data yang digunakan dalam penelitian ini adalah dengan studi kepustakaan yang dilakukan melalui pengumpulan data sekunder, dan data diperoleh dari bahan-bahan pustaka seperti buku-buku dan dokumendokumen tertulis lainnya. Adapun data-data sekunder tersebut terdiri atas:
a) Bahan Hukum Primer
b) Bahan Hukum Sekunder
c) Bahan Hukum Tersier

\section{PEMBAHASAN}

\section{A. Hasil Penelitian}

1. Pengusiran pengungsi Afrika Utara dari Jerman

Setelah kejadian pelecehan seksual yang dilakukan oleh pengungsi yang diduga afrika utara dan timur tengah tersebut, Jerman kemudian memutuskan untuk memulangkan pengungsi secara paksa dan berupaya mempercepat proses deportasi pengungsi Afrika Utara dalam jumlah belasan ribu. ${ }^{9)}$ Kemudian menteri dalam negeri Jerman bersama parlemen Jerman memperketat aturan mengenai penanggulangan terhadap pengungsi, sehingga untuk pengungsi yang masuk harus memiliki kriteria yang khusus

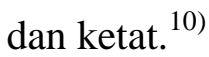

Dalam hal ini, pemerintah di Maroko dan Aljazair sepakat menerima kembali warga negaranya yang mengungsi dengan alasan ekonomi ke Jerman. Kesediaan kedua negara ini membuka jalan proses deportasi cepat. Hal tersebut disepakati setelah Menteri Dalam Negeri

9) Ervan Hardoko, “Jerman Segera Deportasi Masssal Pengungsi Afrika Utara”, http://internasional.kompas.com/read/2016/03/01/19373611/www.dw.com, 9 Februari 2018, hal.1.

10) Yermi Brenner \& Katrin Ohlendorf, Loc.Cit., pg.1. 
Jerman, Thomas de Maizière berkunjung ke Rabat dan Aljir. ${ }^{11)}$ De Maiziere mengakatan bahwa, Ia juga sedang menegosiasikan kesepakatan serupa dengan Tunisia, untuk pemulangan sebanyak mungkin kelompok pengungsi dalam waktu cepat. Pemerintah Jerman menggolongkan Maroko, Aljazair, dan Tunisia sebagai negara aman. ${ }^{12)}$

Pemerintah Maroko berjanji akan memproses kepulangan warganya dalam waktu 45 (empat puluh lima) hari. Menurut pemerintah Jerman, tahun lalu terdapat 27.000 (dua puluh tujuh ribu) pengungsi asal Maroko dan Aljazair datang untuk mencari suaka. Di antara mereka cuma segelintir yang berhak menerima suaka di Jerman. Namun upaya deportasi tidak mudah, karena para pengungsi mampu melenyapkan identitas pribadi dan mengaku sebagai warga negara Suriah. ${ }^{13)}$

Dengan kesediaan negara asal, identitas pengungsi asal Afrika Utara menjadi lebih mudah diketahui lewat sidik jari mereka. Saat ini Jerman akan memulangkan kelompok pertama berjumlah 29 (dua puluh sembilan) orang ke Maroko. Mereka diberikan paspor Laissez-passer oleh Perserikatan Bangsa-Bangsa (yang selanjutnya disebut PBB) untuk pengungsi yang tidak jelas negara asalnya. Upaya Jerman menggandeng negara-negara Afrika Utara adalah salah satu upaya me ngurangi tekanan terhadap kebijakan pengungsi pemerintah. ${ }^{14)}$ Berlin terutama didesak mendeportasi pengungsi asal Maroko sejak insiden pelecehan seksual massal pada malam tahun baru di Köln. Dalam kenyataanya, Aziz Alilou, seorang jurnalis setempat menganggap bahwa tidak terdapat alasan kuat bagi warga Maroko untuk meminta perlindungan di Jerman. Kemudian Die Welt juga berpendapat bahwa pada dasarnya warga Maroko merupakan negara Arab

11) Anonim, "Jerman Deportasi Massal Pengungsi Afrika Utara”, http://www.dw.com/id/jerman-deportasi-massal-pengungsi-afrika-utara/a-19083982, 9 Februari 2018, hal.1.

\footnotetext{
${ }^{12)}$ Anonim, Loc.Cit, hal.1.

${ }^{13)}$ Ervan Hardoko, Loct.Cit, hal.1.

${ }^{14)}$ Anonim, Loc.Cit, hal.1.
} 
paling liberal sehingga alasan mereka datang ke Jerman hanya untuk kehidupan lebih baik saja. ${ }^{15)}$

2. Tindak lanjut UNHCR terhadap pengusiran pengungsi Afrika Utara dari Jerman

UNHCR sebagi suatu lembaga dibawah PBB khusus penangan pengungsi menanggapi pengusiran atau pendeportasian yang dilakukan Jerman terhadap pengungsi Afrika Utara yang melakukan pelecehan seksual pada saat perayaan tahun baru tersebut, dalam wawancara yang dilakukan oleh Yermi Brenner dan Katrin Ohlendorf, dua jurnalis Jerman yang meneliti mengenai kasus pelecehan seksual yang terjadi pada malam tahun baru di cologne. Stefan Teloken salah satu ahli dari UNHCR mengatakan bahwa, deportasi atau pengusiran yang dilakukan oleh Jerman adalah konsekuensi langsung atas perubahan aturan yang dilakukan Jerman terkait pengungsi, yang disebabkan iklim pengungsi menjadi lebih menimbulkan konflik. ${ }^{16)}$

Hal ini juga tidak terlepas bahwa sebagai suatu negara walaupun tetap berpegang pada Konvensi Wina 1951, sebagai suatu negara tidak boleh meninggalkan keamanan dalam negaranya. Sehingga telah dibuat suatu langkah tegas dengan diperbaharuinya aturan-aturan mengenai pengungsi yang terdapat di negara Jerman, sehingga dapat membatasi dan mengurangi kejahatan-kejahatan yang disebabkan pengungsi terhadap keamanan dan ketertiban negara Jerman

3. Penyerangan seksual Pengungsi Afrika Utara di Koln, Jerman

Berdasarkan wawancara yang dilakukan oleh jurnalis Jerman bernama Yermi Brenner dan Katrin Ohlendorf dalam the correspondent, ${ }^{17}{ }^{1}$

${ }^{15)}$ Ervan Hardoko, Loct.Cit, hal.1.

${ }^{16)}$ Yermi Brenner \& Katrin Ohlendorf, Loc.Cit., pg.1.

17) Dalam mencari tahu fakta mengenai kasus penyerangan seksual ini, dua jurnalis jerman bersama Yermi Brenner dan Katrin Ohlendorf yang Penulis kutip ini melakukan beberapa penelitian atas: Satu, analisa laporan-laporan media, termasuk berita rregional, berita nasional dan internasional mengenai kejadian yang terjadi pada malam tahun baru di Koln. Kedua, melihat dua puluh (20) laporan dari dokumen-dokumen asli. Ketiga, melakukan interview terhadap 13 otoritas berwenang. 
Konflik permasalah antara pengungsi Afrika Utara dengan Jerman dimulai sejak terjadinya kasus pelecehan seksual massal pada malam tahun baru di kota Koln, dimana diperkirakan sekitar 1.252 orang yang diduga pengungsi dari Afrika Utara atau Timur Tengah dilaporkan atas penyerangan seksual dan pencurian. ${ }^{18)}$

1.168 laporan diterima oleh kepolisian Koln atas insiden di tahun baru tersebut. Total 492 wanita diantaranya melaporkan adanya tindakan penyerangan seksual, dalam kategori pelecehan sexual, penyerangan dan pemerkosaan dalam laporan kejahatan pada perayaan tahun baru di Koln, 2015/2016 lalu. ${ }^{19)}$

Selanjutnya dalam wawancara Yermi Brenner dan Katrin Ohlendorf terhadap saksi mata bernama Yousef Aljork seorang pencari suaka mengatakan, bahwa pada malam tahun baru itu Aljork pergi ke tengah kota Koln untuk ikut serta dalam perayaan bersama pamannya dan berjalan disekitar stasiun Koln. Kemudian, sekitar jam 11 malam, area stasiun tersebut menjadi sangat penuh oleh orang-orang yang ingin merayakan tahun baru. $^{20)}$

Sekitar tengah malam, semua memburuk, Aljork bersaksi bahwa ia melihat beberapa pria yang diduga 8 sampai 10 orang menjebak satu atau dua orang wanita diantaranya dan mulai menyentuh mereka. Beberapa ada yang mencuri uang, handphone atau hal lainnya. Aljork berkata bahwa dia berkata beberapa orang berbicara dalam bahasa Arab dengan aksen dari Afrika Utara dan diapun melihat ada kelompok Afrika Utara yang juga

Keempat, berbicara dengan 14 saksi mata. Kelima berbicara dengan 6 korban. Ketujuh, interview terhadap ahli dalam pengungsi dan hukum imigrasi, pencari suaka, beberapa media, dan terhadap organisasi terkait pengungsi.

${ }^{18)}$ Yermi Brenner \& Katrin Ohlendorf, "Time for the facts. What do we knwo about Koln four months later?", https://thecorrespondent.com/4401/time-for-the-facts-what-do-we-know-about-Kolnfour-months-later/1073698080444-e20ada1b, 7 may 2018, pg.1.

${ }^{19)}$ Yermi Brenner \& Katrin Ohlendorf, Loc.Cit., pg.1.

${ }^{20)}$ Yermi Brenner \& Katrin Ohlendorf, Loc.Cit., pg.1. 
mengelilingi seorang wanita. Ia tidak berani untuk ikut campur dan bahkan melaporkan pada polisi karena takut akan mempengaruhi setatusnya sebagai pencari suaka yang masi dalam proses. ${ }^{21)}$

Lebih lanjut, adanya kesaksian Kirsten salah seorang korban pada saat kejadian tersebut terjadi, ia mengatakan bahwa sekitar tengah malam, kirsten sedang mengejar kereta untuk keluar dari stasiun tersebut, namun merasa pasrah karena terjebak ditengah-tengah kerumunan tersebut. Pada saat itu, ia merasakan sesuatu yang memegang bagian bawah belakang tubuhnya, yang kemudian ia sadari itu merupakan sebuah tangan. Beberapa menit kemudian hal yang sama terjadi lagi, namun kali ini menuju bagian kemaluannya, dan itu disengaja. Karena ramainya situasi disana, ia berusaha untuk bergerak tapi hanya bisa menggerakan sikunya untuk meraih ponselnya. $^{22)}$ Di sekitarnya, terdapat pemuda yang terlihat merupakan pengungsi yang baru sampai di Jerman. ${ }^{23)}$

\section{B. Analisa}

1. Korelasi antara kebijakan pengungsi negara Jerman terhadap peraturan pidana Jerman atas pelaku pelecehan seksual

Apabila melihat regulasi dari kebijakan pengungsi di Jerman maka Pada seksi 4 ayat (2)c asylum act, pengungsi harus tunduk atas aturan tersebut dan aturan negara Jerman lainnya sebagai suatu syarat dan kewajiban yang harus dilakukan atas proteksi yang diberikan negara kepadanya, terutama dalam hal aturan ini menitik beratkan pada kejahatan yang diatur dalam suatu aturan pidana tertentu di Jerman, yaitu:

${ }^{21)}$ Yermi Brenner \& Katrin Ohlendorf, Loc.Cit., pg.1.

${ }^{22)}$ Yermi Brenner \& Katrin Ohlendorf, Loc.Cit., pg.1.

${ }^{23)}$ Washington post, "2.000 men akkegedky assaulted 1.200 women across Germany on New Year's Eve: leaked police report”, NationalPost.com, 7 june 2018,pg.1. 
These grounds for exclusion shall apply also to foreigners who incite others to commit the crimes or acts listed above or are otherwise involved in such crimes or acts.

Sehingga dalam ayat tersebut, secara tidak langsung pengungsi atau orang asing harus juga menghormati dan mentaati aturan pidana Jerman apabila masih ingin mendapatkan proteksi yang diberikan negara Jerman. Selanjutnya, berdasarkan ayat tersebut Penulis menghubungkan dengan criminal code yang menjadi aturan pidana yang dibuat oleh Jerman sebelum terjadinya pelecehan seksual yang dilakukan oleh pengungsi Afrika Utara tersebut.

Melihat dari criminal code Jerman dalam seksi 177 mengenai sexual coercion;rape, dapat dilihat bahwa suatu tindakan dimana seseorang melakukan pelecehan dengan paksaan atau membuat ancaman atau berdasarkan siatuasi tertentu terhadap orang lain merupakan suatu bentuk tindak pidana yang dapat mengakibatkan adanya hukuman penjara tidak kurang dari 1 tahun. Hal ini membuktikan bahwa pelecehan seksual adalah sautu perbuatan yang melawan hukum di negara Jerman, sehingga apabila dilakukan maka akan dikenakan sanksi pidana.

Dalam hal kasus mengenai pengungsi Afrika Utara yang melakukan pelecehan sesksual dan terbukti berdasarkan data-data yang Penulis telah sertakan dibab sebelumnya. Pengungsi Afrika Utara terikat dengan adanya aturan asylum act bahwa segala bentuk perlindungan diberikan kecuali memang terbukti melakukan suatu tindak pidana berat yang berhubungan dengan HAM, dan keamanan inetrnasional, namun juga dalam seksi ke 4 ayat (2) angka 4 juga menitik beratkan pada suatu perbuatan tindak pidana yang dapat mengganggu ketertiban dan keamanan umum negara Jerman yang kemudian diatur dalam suatu ketentuan-ketentuan pidana lainnya yang berlaku di Jerman. Ketentuan-ketentuan yang dimaksud sebagaimana yang 
Penulis telah jelaskan diatas adalah ketentuan yang terdapat dalam criminal code pada seksi 177 mengenai tindak pidana pelecehan dan pemaksaan seksual yang menurut hukum nasional Jerman adalah suatu perbuatan melawan hukum.

2. Pengusiran pengungsi Afrika Utara yang telah melakukan tindak pidana berdasarkan hukum internasional

a. Dampak pengusiran pengungsi Afrika Utara dari negara Jerman terhadap asas tanggung jawab negara Jerman berdasarkan hukum internasional

Tanggung jawab negara (state responsibility) merupakan prinsip fundamental dalam hukum internasional yang bersumber dari doktrin para ahli hukum internasional. Tanggung jawab negara timbul bila terdapat pelanggaran atas suatu kewajiban internasional untuk berbuat sesuatu, baik kewajiban tersebut berdasarkan perjanjian internasional maupun berdasarkan pada kebiasaan internasional. ${ }^{24)}$

Pasal 1 Draft Articles International Law Comission 2001, menegaskan bahwa setiap tindakan suatu negara yang tidak sah secara internasional melahirkan suatu tanggung jawab. ${ }^{25}$ Prinsip dalam rancangan pasal inilah yang dianut dengan teguh oleh praktek negara dan keputusan-keputusan pengadilan serta telah menjadi doktrin dalam hukum internasional. ${ }^{26)}$

Menimbang hal tersebut, tanggung jawab negara Jerman sebagai suatu negara juga memiliki batasan-batasan yang dapat menentukan apakah negara tersebut sudah atau belum melakukan kewajiban internasional sebagai suatu negara, sehingga setelah terbukti telah melakukan kewajibannya sebagai negara yang melakukan tanggung jawabnya sesuai hukum internasional, maka negara tersebut

24) Andrey Sujatmoko, Tanggung Jawab Negara Atas Pelanggaran Berat HAM: Indonesia, Timor Leste dan Lainnya, (Jakarta: Grasindo Gramedia Widiasarana Indonesia, 2005), hal.28.

25) Sefriani, Hukum Internasional: Suatu Pengantar, (Jakarta: PT. Raja Grafindo Persada, 2010), hal.266.

26) Huala Adolf, Aspek-aspek Negara dalam Hukum Internasional, (Jakarta: CV. Rajawali, 1991), hal.174. 
memiliki hak nya untuk juga untuk segala dampak yang terjadi setalahnya. Berdasarkan data yang Penulis miliki, bahwa negara Jerman telah menerima pengungsi dari Afrika Utara dan Timur Tengah sebagai suatu kewajiban internasional atas turut sertanya negara Jerman dalam penandatanganan Konvensi Wina 1951 tentang pengungsi, namun melihat kasus pelecehan seksual pada warga Koln di malam tahun baru yang telah dibuktikan dalam data yang telah Penulis sertakan pada Bab III makalah ini, maka adalah suatu kewajiban negara untuk melindungi warga negaranya, sehingga harus mengambil suatu keputusan untuk mengusir pengungsi dari Afrika Utara serta memperbaharui aturanaturan mengenai pengungsi dinegaranya.

b. Pengecualian asas larangan pengusiran pengungsi (non-refoulment) bertentangan dengan Konvensi WINA 1951 tentang Pengungsi.

Prinsip non-refouelement yang mencerminkan perlindungan minimum berdasarkan alasan kemanusiaan yang tercantum dalam Pasal 33 Konvensi 1951, menerangkan larangan memaksa pengungsi kembali ke negara di mana ia mungkin mengalami persekusi tidak diterapkan kepada pengungsi yang mengancam keamanan negara, atau ia telah mendapatkan putusan akhir dari hakim atas kejahatan serius yang telah ia perbuat, serta membahayakan masyarakat negara setempat. Namun, ketentuan ini hanya berlaku untuk perkecualian yang sangat mendesak. Hal tersebut bermakna, apabila perkecualian tersebut akan diterapkan, maka harus dibuktikan bahwa terdapat hubungan langsung antara keberadaan pengungsi di suatu negara dan keamanan nasional negara itu yang terancam. ${ }^{27)}$

27) Anonim, "Human Rights Implications of European Union Internal Security Proposals and Measures in the Aftermath of the 11 September Attacks in the United States", http://www.hrw.org/press/2001/11/eusecurity.html., 9 Februari 2018, hal.1. 
Berdasarkan Pasal 32 Ayat (2) Konvensi 1951, Pengusiran pengungsi yang sedemikian itu hanya akan dilakukan sebagai pelaksanaan suatu keputusan yang dicapai sesuai dengan proses hukum yang semestinya, kecuali apabila alasan-alasan keamanan nasional yang bersifat memaksa mengharuskan lain, pengungsi itu akan diizinkan menyampaikan bukti untuk membersihkan dirinya serta mengajukan banding kepada instansi yang berwenang.

Pada intinya pengecualian penerapan non-refoulement mensyaratkan adanya unsur ancaman terhadap keamanan negara dan gangguan terhadap ketertiban umum di negara setempat. Ancaman meliputi hambatan, tantangan dan gangguan. ${ }^{28)}$ Dalam arti sempit, ancaman dapat bersifat terencana ataupun residual. Ancaman terencana dapat berupa subversi maupun pemberontakan dalam negeri maupun infiltrasi, subversi, sabotase dan invasi. Ancaman residual adalah berbagai keadaan dalam masyarakat yang merupakan kerawanan ekonomi, sosial dan politik yang apabila tidak ditangani secara tuntas pada waktunya, akan memicu kerusuhan yang dapat dipergunakan oleh unsur-unsur subversi atau pemberontak untuk kepentingannya. ${ }^{29)}$

Dapat dimaklumi bahwa arus pengungsi dalam jumlah besar dapat membebani perekonomian, mengubah keseimbangan etnis, menjadi sumber konflik, yang bahkan dapat mengakibatkan kekacauan politik tingkat lokal maupun nasional di suatu negara. ${ }^{30)}$ Walter Lippmann sebagaimana dikutip Kusnanto Anggoro, menyatakan bahwa suatu negara berada dalam keadaan aman selama bangsa itu tidak dapat dipaksa untuk mengorbankan nilai-nilai yang dianggapnya penting (vital) dan jika dapat menghindari perang atau jika terpaksa berperang,

28) Sjaafroedin Bahar dkk, Pendidikan Pendahuluan Bela Negara Tahap Lanjutan, (Jakarta: Intermedia, 1994), hal.68.

29) Ibid., hal.71.

${ }^{30)}$ Myron Weiner, Op. Cit., hal.131. 
dapat keluar sebagai pemenang. ${ }^{31)}$ Sementara itu ketertiban umum adalah suatu keadaan di mana pemerintah dan rakyat dapat melakukan kegiatan secara tertib dan teratur.

Sehingga pada pertimbangan diatas, bahwa tindakan pengusiran yang dilakukan oleh Jerman pada dasarnya tidak bertentangan dengan asas non-refoulment yang terdapat dalam hukum internasional. Dilain sisi, pengungsi Afrika Utara telah terbukti melakukan tindak pidana pelecehan seksual dan kejahatan lainnya pada malam tahun baru di Koln, Jerman yang dibuktikan oleh adanya laporan kepolisian, beberapa foto dan kesaksian-kesaksian yang ada.

3. Tanggungjawab UNHCR sebagai Organisasi Internasional dalam pengusiran pengungsi.

a. Asas Legal Personlity dalam UNHCR terhadap pengusrian pengungsi Afrika Utara

Suatu organisasi internasional memiliki suatu atribut-atribut yang membuatnya memiliki suatu kekuatan hukum untuk menggugat atau memberi sanksi kepada subjek hukum lainnya. Atau sebaliknya, apakah subjek hukum lain dapat menggugat organisasi internasional atau tidak. Jawabannya terletak pada alat utama organisasi terkait, yakni perjanjian, konvensi, piagam, atau resolusi. Jika secara tertulis sudah tersedia aturanaturan terkait dapat atau tidaknya suatu organisasi internasional menggugat subjek lain, maka pertanyaan tersebut mudah diijawab. Beberapa pengadilan dan ilmuwan menyatakan bahwa sebuah atribut melekat dengan organisasi internasional. Atribut ini diberikan hukum internasional kepada organisasi internasional, terpisah dengan atribut negara anggotanya. Atribut inilah yang disebut legal personality. ${ }^{32)}$

31) Kusnanto Anggoro, "Keamanan Nasional, Pertahanan Negara dan Ketertiban Umum”, makalah pembanding dalam Seminar Pembangunan Hukum Nasional VIII, 2003, hal.1.

${ }^{32)}$ Sean D. M, Principles of International Law, (USA, 2006), pg.41-42. 
Dengan adanya legal personality ini maka organisasi internasional tersebut menjadi subjek hukum internasional, sehingga menimbulkan hak dan kewajiban menurut hukum internasional. Hak dan kewajiban tersebut antara lain mempunyai wewenang untuk menuntut di depan pengadilan, sebaliknya juga dapat dituntut, memperoleh dan memiliki benda-benda bergereak, mempunyai kekebalan (immunity) dan hak-hak istimewa, ${ }^{33)}$ Sesuai dengan article 8 dan 9 statuta UNHCR yang menjelaskan kewajiban yang timbul bagi UNHCR sebagai suatu organisasi internasional yang memiliki legal personality adalah untuk melindungi dan membantu pengungsi seperti yang telah tertera dalam artikel 8 dan 9. ${ }^{34)}$ Terutama pada artikel 9, UNHCR sebagai komisi tinggi harus menyediakan pemindahan tempat dan pemukiman bagi pengungsi. Hal ini menjadikan UNHCR mendapatkan kewajiban untuk mencarikan dan mengurus perlindungan bagi pengungsi yang diusir, karena tidaklah mungkin pengungsi tersebut kembali kenegaranya, padahal seseorang yang telah memiliki status pengungsi, memilki sertifikat khusus pengungsi yang dikeluarkan oleh UNHCR, karena nyawanya terancam apabila tetap tinggal di negaranya, sehingga memiliki perlindungan khusus dari UNHCR sebagai komisi tinggi PBB dalam urusan pengungsi. Dari kewajiban ini apabila tidak dilakukan oleh pihak UNHCR maka menimbulkan suatu tanggungjawab organisai internasional, yang harus bertanggungjawab atas pemulangan secara paksa pengnugsi Afrika Utara tersebut dari Jerman.

${ }^{33)}$ Sri Setianingsih Suwardi, Pengantar Hukum Organisasi Internasional, (Jakarta: Penerbit Universitas Indonesia, 2004), hal.3.

${ }^{34)}$ Dalam bukunya Sri Setianingsih Suwardi, menjelaskan bahwa hak dan kewajiban organisai internasional adalah hak dan kewajiban yang benar-benar hak dan kewajiban organisasinya bukanlah hak dan kewajiban negara-negara penandatangan. Maka dari itu UNHCR sebagai pengungsi memilki hak dan kewajibannya yang tertuang dalam statuta UNHCR. 
b. Tindak lanjut UNHCR atas pengusiran pengungsi Afrika Utara yang dilakukan Jerman

Sebagai suatu Organanisasi Internasional, UNHCR tentunya terikat dengan Anggaran Dasar Organisasinya yang tertuang dalam Statuta UNHCR dalam melaksanakan tugas dan kewajibannya menanggulangi orang-orang yang mencari perlindungan di negara-negara lain. Dalam pelaksanaanya UNHCR memberikan dukungan besar dalam pemberian suaka dengan pemberian izin bagi pencari suaka untuk berada di Indonesia, memperoleh layanan UNHCR dan izin tinggal sementara di Indonesia selama mereka menunggu solusi jangka panjang yang sesuai bagi mereka.

Solusi jangka panjang yang ada terdiri dari integrasi lokal, pemulangan secara sukarela, atau penempatan di negara ketiga. Namun, akibat keterbatasan kuota penempatan di negara ketiga yang tersedia di dunia. UNHCR dalam beberapa tahun belakangan ini berusaha memperluas alternatif, mencari lebih banyak solusi "jangka panjang” yang diterangkan dibawah ini: ${ }^{35)}$

\section{1) Integrasi Lokal (local Integration)}

Integrasi Lokal (local Integration) merupakan upaya pengungsi dalam mencari rumah di negara suaka dan mengintegrasikan pengungsi ke dalam masyarakat setempat. Hal ini merupakan solusi berkelanjutan yang dilakukan UNHCR untuk menghindari penderitaan pengungsi dan kesempatan untuk memulai hidup baru. Integrasi lokal merupakan proses bertahap yang terdiri dimensi hukum, ekonomi, sosial dan budaya untuk menyatukan perbedaan

35) UNHCR, "Solusi Komprehensif", http://www.unhcr.org/id/solusi-komprehensif, 29 Mei 2018, hal.1. 
Antara pengungsi dan masyarakat penerima. ${ }^{36}$ Tujuan integrasi di negara pemberi suaka adalah untuk membantu pengungsi agar menjadi mandiri di negara suaka. Integrasi lokal tersebut dilakukan dengan berbagai cara, seperti dengan memberikan pelatihan melalui sekolah - sekolah keterampilan atau pekerjaan berdagang. ${ }^{37}$

2) Repatriasi Sukarela (Voluntary repatriation)

Repatriasi Sukarela (Voluntary repatriation), merupakan solusi jangka panjang yang paling baik bagi mayoritas pengungsi. Mayoritas pengungsi memilih untuk kembali ke negara asal setelah keadaan di negara asal telah stabil. Oleh karena itu, UNHCR mendukung repatriasi sukarela sebagai solusi yang terbaik bagi pengungsi dengan syarat keadaan telah aman dan kemungkinan repatriasi sangat besar.

Dalam menjalankan repatriasi sukarela UNHCR menyediakan transportasi dan paket pemula yang terdiri dari bantuan uang, proyek binakarya dan bantuan praktis seperti peralatan tani dan benih. UNHCR juga bekerja sama dengan mitra Lembaga Swadaya Masyarakat (LSM) dalam menjalankan repatriasi sukarela dengan menyalurkan bantuan pembangunan kembali rumah - rumah penduduk maupun infrastuktur umum seperti gedung sekolah, klinik, jalan, jembatan dan sumur. ${ }^{38}$

3) Pemukiman Kembali (Resettlement)

Pemukiman Kembali (Resettlement) merupakan salah satu solusi UNHCR dalam mengupayakan pemukiman ke negara ketiga. Hal itu dilakukan karena dalam situasi konflik, pengungsi tidak

\footnotetext{
${ }^{36}$ Muhammad Yazid, "Eksistensi United Nation High Commissioner of Refugees (UNHCR)”, Makalah, (UNPAS, 2017), hal.15-16.

${ }^{37}$ Achmad Romsan, Pengantar Hukum Pengungsi Internasional, ( Bandung : Sainc Offset, 2003 ), 167

${ }^{38}$ Muhammad Yazid, Loc.Cit.
} 
mungkin untuk kembali adalah mengadakan perjanjian dengan pemerintah negara penerima untuk menyediakan pemukiman yang cocok dan layak bagi pengungsi. UNHCR juga mendorong pemerintah negara penerima pengungi untuk melonggarkan kriteria penerimaan pengungsi dan menetapkan prosedur keimigrasian khusus bagi para pengungsi. ${ }^{39}$

Hal ini berarti mencari solusi yang disesuaikan atau solusi individual untuk mendukung individu atau keluarga bersangkutan, dengan solusi yang layak bagi konteks mereka. Seiring dengan berkurangnya kuota penempatan di negara ketiga secara global, fokus UNHCR beralih kepada kesempatan penghidupan, keahlian, dan pengembangan kapasitas serta pelatihan kejuruan

Melihat perkembangan dalam kasus pemulangan secara paksa pengungsi Afrika Utara yang dilakukan oleh Jerman, UNHCR bertanggungjawab atas pemulangan para pengungsi ke negara asalnya. Sedangkan dapat kita ketahui pemulangan ke negara asal hanya dapat dilakukan dengan kesukarelaan para pengungsi itu sendiri, dan bukanlah kesepakatan hanya diantara dua (2) negara yang bersengketa tanpa melihat dari perlindungan individu yang hendak meminta perlindungan, serta alasan para pengungsi tersebut mendapatkan status pengungsi dari UNHCR.

\section{PENUTUP}

Dalam bab penutup, Penulis akan memberikan kesimpulan dari permasalahan yang menjadi isu hukum dalam penelitian ini serta memberikan saran, sehingga

\footnotetext{
${ }^{39}$ Damiko Bautista, Struktur badan PBB uusan pengungsi ( UNHCR) beserta mandatnya.(Jakarta: Tanpa Tahun), 168.
} 
penelitian ini dapat memberikan manfaat bagi kalangan akademisi, praktisi, serta masyarakat luas.

A. Kesimpulan

Berdasarkan hasil penelitian dan pembahasan yag telah dipaparkan oleh Penulis dalam bab-bab terdahulu, maka kesimpulan yang dapat diambil adalah

1. Mengenai pertanggung jawaban Negara Jerman atas pengusiran secara paksa pengungsi Afrika Utara yang timbul akibat keputusan negara Jerman yang dianggap bertentangan dengan prinsip hukum internasional, yaitu prinsip nonrefoulement adalah tidak dapat diminta pertanggung jawaban. Berdasarkan penelitian yang dilakukan penulis bahwa benar pengungsi Afrika Utara terbukti dalam melakukan pelecehan dan penyerangan seksual pada malam tahun baru di Koln, sehingga apabila kita melihat pada Pasal 33 ayat (2) Konvensi 1951, yang menjadi dasar pengusiran merupakan bentuk konsekuensi dari tindakan yang dilakukan oleh pengungsi-pengungsi tersebut karena telah terbukti telah melakukan kejahatan serius dan membahayakan keamanan dan kestabilan keamanan Negara Jerman. Dalam hal ini menyebabkan gugurnya perlindungan non-refoulment yang melindungi para pengungsi yang menjadi jaminan mereka untuk memperoleh keamanan dan izin tinggal di negara penerima suaka.

Apabila melihat dari sisi pelanggaran hak asasi yang dimiliki pengungsi sebagai pengungsi yang di lindungi oleh hukum internasional, tentunya ada benarnya apabila pengungsi yang merupakan individu adalah 
subjek hukum internasional, sehingga dalam pelaksanaanya pengusiran kembali ke negara asalnya, padahal seperti yang diketahui bahwa pada pertengahan 2016, Maroko masi banyak teror-teror yang dilakukan oleh ISIS yang juga akan mempengaruhi keselamatan para pengungsi yang dikembalikan ke negara asalnya ini. Namun, sebagai suatu negara Jerman juga memiliki kedaulatan untuk menjalankan hukum nasional dan wilyahnya sehingga, sebuah keputusan yang Jerman lakukan tidak lain untuk menuntut hak-hak warga negaranya untuk memperoleh keamanan dan kesejahteraan yaang telah hilang akibat adanya insiden penyerangan dan pelecehan seksual oleh pengungsi Afrika Utara tersebut. Hal ini juga mendapat desakan dari partai pemerintah oposisi beserta dengan masyarakat yang mulai menyuarakan anti-pengungsi.

2. Mengenai pertanggung jawaban UNHCR sebagai komisi tinggi PBB dalam melindungi pengungsi yang diusir. Bersadarkan data yang telah diteliti oleh Penulis, bahwa UNHCR dapat bertanggungjawab dikarenakan sebagai organisasi internasional, UNHCR memiliki legal personality sehingga didalamnya memiliki kekuatan hukum untuk melakukan perbuatan hukum. Dimana legal personality ini juga menimbulkan hak dan kewajiban bagi organisai internasional ini. Sebagai organisasi yang memiliki hak dan kewajiban, maka diaturlah dalam anggaran dasar organisai internasional yang tertuang dalam Statuta UNHCR, berdasarkan hal tersebut diatur dalam Statuta UNHCR khususnya Pasal 8 dan 9, bahwa UNHCR harus memberikan 
perlindungan terhadap pengungsi termasuk dalam hal penempatan kembali para pengungsi-pengungsi ini. Serta berdasarkan bentuk dari solusi jangka panjang yang dikeluarkan oleh UNHCR seharusnya pengusiran dan pengembalian ke negara asal dapat dihindarkan, berhubung karena keselamatan para pengungsi dan mengingat asal asul pengungsi memperoleh status pengungsi karena terancamnya nayawa mereka di negara asalnya. Sehingga UNHCR masih memiliki kewajiban untuk melindungi pengungsipengungsi ini, dan menjadi tanggungjawab UNHCR apabila keselamatan pengungsi ini kembali terancam ketika kembali ke negaranya. Seperti yang telah penulis sebelumnya, bahwa keadaan dan keamanan Negara Afrika Utara, masihlah belum stabil sehingga sangatlah membahayakan untuk mengembalikan para pengungsi tersebut ke negara asalnya, sedangkan sertifikat perlindungan pengungsi yang diberikan oleh UNHCR masih berlaku dalam hal perlindungan oleh UNHCR, karena UNHCRlah yang mengeluarkan sertifikat perlindungan pengungsi dan juga sebagai koordinator perlindungan terhadap pengungsi-pengungsi ini.

B. Saran

Saran yang dapat Penulis berikan adalah seharusnya berdasarkan solusi jangka panjang yang dikeluarkan oleh UNHCR dan melihat dari Pasal 8 dan 9 Statuta UNHCR, UNHCR seharusnya memberikan perlindungan terdahap pengungsi-pengungsi yang di usir, dengan memberikan suaka sementara di tempat-tempat khsusu yang dimiliki UNHCR untuk memberikan penampungan 
sementara terhadap para pencari suaka yang kemudian diberikan penempatan kembali terhadap negara ke tiga yang mau menerima lagi para pengungsi UNHCR. Sehingga pengungsi ini tetap terjamin dalam hal keamanan dan nyawanya dengan tidak dikembalikan ke negara asalnya.

\section{DAFTAR PUSTAKA}

\section{A. Buku}

Adolf, Huala. Aspek-aspek Negara dalam Hukum Internasional. (Jakarta: CV. Rajawali, 1991).

Bahar, Sjaafroedin, dkk. Pendidikan Pendahuluan Bela Negara Tahap Lanjutan. (Jakarta: Intermedia, 1994).

Bautista. Damiko Struktur badan PBB uusan pengungsi ( UNHCR) beserta mandatnya. (Jakarta: Tanpa Tahun).

D, Sean M. Principles of International Law. (USA, 2006).

Diantha, I. Made Pasek. Metodologi Penelitian Hukum Normatif dalam Justifikasi Teori Hukum. Cetakan ke-1. (Jakarta: Kencana Prenada Media Group, 2016).

IJastram, Kate and Marilyn Achiron. Refugee Protection: A Guide to International Refugee Law. (Switzerland: Inter-Parliamentary Union, 2001).

Sefriani. Hukum Internasional: Suatu Pengantar. (Jakarta: PT. Raja Grafindo Persada, 2010).

Setianingsih, Sri Suwardi. Pengantar Hukum Organisasi Internasional. (Jakarta: Penerbit Universitas Indonesia, 2004).

Soekanto, Soerjono. Pengantar Penelitian Hukum. Cetakan ke-3. (Jakarta: UI Press, 1986). 
Sujatmoko, Andrey. Tanggung Jawab Negara Atas Pelanggaran Berat HAM:

Indonesia, Timor Leste dan Lainnya. (Jakarta: Grasindo Gramedia Widiasarana Indonesia, 2005).

Suriasumantri, Jujun S. Filsafat Ilmu. Cetakan ke-3. (Jakarta: Pustaka Sinar Harapan, 1987).

Wagiman. Hukum Pengungsi Internasional. (Jakarta: Sinar Grafika, 2012).

\section{B. Konvensi dan Perjanjian Internasional}

Universal Declaration of Human Rights (1948).

Konvensi Wina Tahun 1951 Tentang Status Pengungsi (The 1951 Convention Relating Status of Refugees)

International Convenant On Civil and Political Rights (1966).

The United Nations Declaration on Territorial Asylum (1967).

Protokol tahun 1967 Tentang Status Pengungsi (Protocol Relating to the Status of Refugees 1967).

UNCHR, Melindungi Pengungsi dan Peran UNCHR, Penerbit UNCHR, 2007.

\section{Jurnal}

Kusnanto Anggoro. "Keamanan Nasional, Pertahanan Negara dan Ketertiban Umum”. Makalah pembanding dalam Seminar Pembangunan Hukum Nasional VIII yang diselenggarakan oleh Badan Pembinaan Hukum Nasional, Departemen Kehakiman dan HAM RI. (Denpasar, Bali: Hotel Kartika Plaza, 14 Jull 2003).

Yazid, Muhammad. "Eksistensi United Nation High Commissioner of Refugees (UNHCR)". Makalah. (UNPAS, 2017).

\section{Internet}

Anonim. "Dengan 1 dari 113 orang yang terkena dampaknya, perpindahan terpaksa mencapai rekor tertinggi". http://www.unhcr.org/id/wpcontent/uploads/sites/42/2017/05/wrdreleasebhs16.pdf, 6 Maret 2018. 
Anonim. "Jerman Deportasi Massal Pengungsi Afrika Utara". http://www.dw.com/id/jerman-deportasi-massal-pengungsi-afrikautara/a-19083982, 9 Februari 2018.

Brenner, Yermi \& Katrin Ohlendorf. "Time for the facts. What do we knwo about Cologne four months later?". https://thecorrespondent.com/4401/time-for-the-facts-what-do-weknow-about-cologne-four-months-later/1073698080444-e20ada1b. 7 may 2018.

Hardoko, Ervan. "Jerman Segera Deportasi Masssal Pengungsi Afrika Utara”. http://internasional.kompas.com/read/2016/03/01/19373611/www.dw.co $m, 9$ Februari 2018.

Post, Washington. "2.000 men akkegedky assaulted 1.200 women across Germany on New Year's Eve: leaked police report”. www.NationalPost.com. 7 june 2018.

UNHCR. "Solusi Komprehensif”. www.unhcr.org/id/solusi-komprehensif. 29 Mei 2018. 